\title{
IMPROVEMENT OF CLAYEY SOIL DRAINAGE IN DAKAHLIA GOVERNORATE
}

\author{
Elbanna, E. B.; M. M. Ibrahim; A. E. Abou EL-Magd and \\ H. E. Dewedar \\ Agric. Eng. Dept., Fac. Agric., Mansoura Univ.
}

\begin{abstract}
Sub-soiling system was conducted in order to alleviate the disadvantage which developed by soil compaction. A comparison made between field treatments which tilled by chisel plough at $20 \mathrm{~cm}$ depth and the technique of sub-soiler plough with differences in the sub-soiling depths $(25,50$, and $75 \mathrm{~cm})$ and the lateral spaces between sub-soiling ruts $(200,400$, and $800 \mathrm{~cm})$. Each techniques of the sub-soiling depth were replicated with all of the different distance of lateral spaces between subsoiling ruts. The aim of the comparison was to indentify the most effective sub-soiling technique which produce more enhancement of soil physical properties, achieve the best distribution of soil moisture content and achieve the highest rate of soil water flux. Results indicated that, the plot of soil which was tilled at $75 \mathrm{~cm}$ with a lateral space of $200 \mathrm{~cm}$, recorded the lowest moisture content values and exhibited the highest values of soil penetration resistance. It exhibited more enhancement of soil physical properties as the action of the excess loosening occurred from the deep tilling with the narrower lateral space lead to increases soil porosity, improve permeability, decrease soil strength to low values in comparison with their values before sub-soiling. The soil plot which tilled at $50 \mathrm{~cm}$ with a lateral space of $200 \mathrm{~cm}$ were also achieved more enhancements. Those plots were also recorded high correlation coefficient consideration to the three irrigations. It was found 95.16 and $94.97 \%$ at the first irrigation, 95.54 and $95.47 \%$ at the second irrigation and 95.45 and $95.28 \%$ at the third irrigation for the plots of 75 and $50 \mathrm{~cm}$, sub-soiler depth and $200 \mathrm{~cm}$, lateral space respectively. Values of soil bulk density which obtained after the three irrigations for all the sub-soiling plots decreased from the values obtained before subsoiling. And the lowest values were found at the top surface layer, this was due to tilling with chisel plough at $20 \mathrm{~cm}$ depth where, a more pulverization occurred in the top layer. The higher rate of soil water flux was exhibited from the plots which were tilled at 75 and $50 \mathrm{~cm}$, with a lateral space of $200 \mathrm{~cm}$, followed by the plots which were tilled at 75 and $50 \mathrm{~cm}$, with a lateral space of $400 \mathrm{~cm}$. and high correlation coefficient of $98.62 \%$ was obtained from statistical analysis made using the drainage equations. From the obtained results, it can be concluded that, the lateral space between sub-soiling ruts decreases with an increase in the tillage depth, the soil achieve more enhancement of soil physical properties and exhibit higher rate of soil water flux.
\end{abstract}

\section{INTRODUCTION}

Soil compaction is a big challenge in the management of poor clay soil drainage. Soil compaction is the result of using the heavy tillage equipment during soil cultivation or result from the heavy weight of field equipment used during the crop duty operation and crop harvest. Compacted soils can also be the result of natural soil-forming processes such as wetting and drying. The more compaction formed in the soil, a hardpan underneath are created at a depth immediately or other than immediately below the tilled 
layer in the soil profile. This hardpan layer can hinder the movement of water, prevent root distribution and extension to penetrate the deeper soil layers. Soil compaction has a number of negative effects on soil quality and crop production. It causes soil particles to become compacted closer together into a smaller volume. As particles are compressed together, the space between particles (pore space) is reduced, thereby reducing the space available in the soil for air and water, reduces water infiltration rate into soil as it decreases the water rate which penetrate into the soil root zone and subsoil, reduce the ability of a soil to hold water and air, which are necessary for plant root growth, limits soil exploration by roots and decreases the ability of crops to take up nutrients and reduces crop yield.

Hong-ling et al. (2008) studied the effects of subsoiling on soil moisture content under no-tillage. They showed that subsoiling induced higher soil water storage in $0-100 \mathrm{~cm}$ than no- subsoiling as control, especially in the drought season. The effect of subsoiling on soil water content can also be seen from the vertical distribution in soil profile in $0-100$ $\mathrm{cm}$ between the two treatments. When it was rainy, subsoiling could take up more rainfall to be stored in deep soil layer, and when it was droughty, more water from deep soil layer was utilized by hulless oat plants, which led to a high water use consumption. Consequently, subsoiling caused increase of water use consumption by $16.8 \%$ and crop yield by $18.29 \%$.

Borghei et al. (2008) found that, prior to tillage practices, the average bulk density values at soil layers of $0-20,20-40$, and $40-60 \mathrm{~cm}$ were 1.24 1.48 and $1.65 \mathrm{~g} \mathrm{~cm}^{-3}$, respectively. The highest decrease in bulk density was observed in subsoiling treatments, while the least one was in conventional tillage. Working depth did not create significant effect on soil bulk density. Bulk density decreased in subsoiling treatments compared to conventional tillage in $20-40 \mathrm{~cm}$ depth range showing compacted soil layer in this depth range. This observation is in close agreement with the results obtained on penetration resistance.

Elbanna (2001) and Elbanna and Witney (1987) developed soil strength equation as a function of the soil type (in terms of the clay ratio), soil specific weight and soil moisture content, the developed soil strength equation was:

$$
\mathrm{CI}=\left[\mathrm{K}_{\mathrm{c}} \cdot \mathrm{Cr} \cdot \mathrm{e}^{-0.01 \theta /(1+\mathrm{Cr})}+\mathrm{k}_{\Phi} \frac{\gamma}{1+2 \mathrm{Cr}}\right] \mathrm{e}^{\pi /(1+2 \mathrm{Cr})} \ldots \ldots \ldots .(\mathbf{l})
$$

where:

$$
\begin{aligned}
& \mathrm{Cl}=\text { cone index, } \mathrm{MPa} ; \quad \mathrm{Cr}=\text { clay ratio= \%clay } /(\% \text { silt }+\% \text { sand }) ; \\
& \Theta=\text { soil moisture content, \%; } \quad \gamma=\text { soil specific weight, } \mathrm{kN} / \mathrm{m3} ; \\
& \phi=\text { soil internal shearing frictional angle, deg; } \\
& \mathrm{K}_{\mathrm{c}}=\text { cohesive coefficient, } 3.63 ; \quad \mathrm{K}_{\phi}=\text { frictional coefficient, } 0.0066 . \\
& \tan \phi=\text { tangential friction angle }=1 /(1+2 \mathrm{Cr}) ;
\end{aligned}
$$

Elbanna et al. (2010) reported that cone index "soil strength", proctor test and soil vane shear are another aspect of root growing or elongation which lead to high inflict of crop yield. Therefore, the soil strength properties were evaluated during and at the end of the growing seasons in two tested 
fields, just before each of 5 irrigations during winter crop growing season. It is concluded that measurement one of them that enough to give an indication of soil strength. Elbanna (2001). on three soil strength force methods of cone index (penetrometer), proctor test (proctor penetrometer) and soil vane shear. $\mathrm{He}$ concluded that the readings obtained by cone penetrometer equal 10 times of soil vane shear reading. While the reading obtained by using proctor penetrometer was equal 1.5-1.75 times the once taken by cone penetrometer.

Witney (1988) reported that the hydraulic conductivity is constant for saturated soils but as the soil dries out, water moves primarily in small pores and through films located around and between the soil particles. With decreasing soil moisture content, the cross-sectional area of water films is reduced and the water flow paths become more limited. In consequence, the hydraulic conductivity falls very rapidly with decreasing soil moisture content. The hydraulic conductivity and hence the drainage rate reaches a constant upper limit when the soil is at saturation and either ceases or reaches a negligible value when the soil moisture content approaches field capacity.

Thomas et al. (1994) reported that, field capacity is especially dependent up on soil profile characteristics. Field capacity of a soil is the approximate water through the soil profile due to gravity becomes negligible, generally within a few hours to a few days after through wetting depending upon soil texture, structure and layering (i.e. finer textured soils take longer to drain). Field capacity is generally taken as the upper limit of plant available soil water. He stated that, the plant available water holding capacity is defined as the difference between field capacity and permanent wilting point. Neither of these is a unique function of surface soil properties. According to Allen et al. (1998) soil water availability refers to the capacity of a soil to retain water available to plants. The total available water in the root zone is the difference between the water content at field capacity and wilting point.

Prinzio et al. (1996 and 1997) compared three sub soiling techniques (conventional subsoilers, winged subsoil, and rigid tine subsoiler followed by conventional subsoilers). Their evaluation parameters were: the increase in the soil volume, disturbed soil area, decreases the specific resistance and bulk density. They found that at a depth of $55-60 \mathrm{~cm}$, the winged sub soilers gave a greater increase in soil volume with a larger disturbed soil area. The previous passage of rigid tines showed similar results with improved work quality. They concluded that, at a depth of $25-30 \mathrm{~cm}$, the three tested sub soiling techniques produced similar results.

Nitant et al. (1995) reported that deep tillage operation (under $40 \mathrm{~cm}$ depth) reduced water and nutrient losses through weed uptake, enhanced profile water storage, improved soil properties and suppressed weed growth. They compared some deep tillage operations (under $40 \mathrm{~cm}$ depth) with other shallow tillage operations (up to $20 \mathrm{~cm}$ depth). They found that, deep tillage operations were superior to shallow tillage treatments. They added that deep tillage with sub-soiling chisel also induced deeper root penetration by 34 and $39 \mathrm{~cm}$ more than the shallow tillage treatment.

Elbanna (1993) tried semi-log relationships for four different soils at 
three different depth in order to develop a general productive drainage equation. In theory, hydraulic conductivity and drainage, is constant when soil is at saturation, and either ceases or reaches to a negligible value when the soil moisture content approaches to the field capacity. Of the numerous equations examined the following equation to predict water flux, $\mathrm{mm} /$ day, as exponential function of soil moisture content $\mathrm{mm}$ at previous day profile depth

$$
\ln Q_{D}=5.65\left\{\theta_{m-1}\right\} \backslash h \quad \therefore Q_{D}=e^{5,65}\left\{\theta_{m-1} / h\right\} \ldots \ldots . .(2)
$$

where

$\mathrm{Q}_{\mathrm{D}}=$ drainage flow, $\mathrm{mm} /$ day; $\quad \mathrm{h}=$ soil profile depth, $\mathrm{mm}$;

$\theta_{\mathrm{m}-1}=$ soil moisture content on previous day, $\mathrm{mm} /$ day.

Elbanna (2008) discussed the following equations for calculating the soil water flux beneath soil profile and demonstrated that, the drainage or water flux from the soil, in $\mathrm{mm} /$ day was predicated as an exponential function of soil water content $\mathrm{mm}$, and hydraulic conductivity $\mathrm{mm} /$ day for each soil profile depth. The data obtained for both measured and predicted water flow, was compared with a high correlation co-efficient of $r^{2}=95 \%$.

$$
\mathrm{Q}_{\mathrm{d}}=\mathrm{e}^{\mathrm{KIn}\left(\boldsymbol{\theta}_{\mathrm{m}-1}\right)}
$$

where:

$\mathrm{Q}_{\mathrm{d}}=$ drainage flow, $\mathrm{mm} /$ day; $\quad \mathrm{K}=$ hydraulic conductivity, $\mathrm{mm} /$ day;

$\Theta_{\mathrm{m}-1}=$ soil moisture content on previous day, $\mathrm{mm}$.

$$
\mathrm{Q}_{\mathrm{d}}=\mathrm{e}^{\mathbf{K}_{\mathbf{d}}{ }^{\left(\boldsymbol{\theta}_{\mathrm{m}-1}\right)}}
$$

where:

$Q_{d}=$ drainage flow, mm/day;

$\Theta_{\mathrm{m}}-1=$ water content on the previous day, $\mathrm{mm}$.

$\mathrm{K}_{\mathrm{d}}=$ coefficient constant values, $(4.3,4.71$ and 5.32 as a mean values for the studied layers $A, B$ and $C$, respectively);

Elbanna et al. (2010) showed that, soil water movement can be predicted also using sub-soiling method before traditional tillage improves clay and heavy clay soils propertied and their porosity, and the declination of water movement from middle spacing between sub-soiling ruts was predicted as a function of water precipitation or irrigation, $\mathrm{mm} /$ day, difference soil moisture, $\mathrm{mm}$ and ratio of horizontal/depth of sub-soiling ruts. So drainage factor $Q_{f}$ can be evaluated from predicted regression equation with high degree of explanation as in the form:

$$
\left.Q_{\mathbf{f}}=16.957 K_{i} Q_{i r}+\operatorname{0.042K}_{\theta}\left(\frac{Q_{m}-Q_{c}}{100}\right) \frac{\rho_{b}}{\rho_{w}} h+(-0.0279) K_{s d} \frac{S_{d}}{D_{d}} \ldots \ldots . .5\right)
$$

where: 
$\mathrm{Q}_{\mathrm{f}}=$ drainage factor, $\mathrm{mm} /$ day; $\quad \mathrm{Q}_{\mathrm{ir}}=$ irrigation/ or precipitation, $\mathrm{mm} /$ day; $\mathrm{Q}_{\mathrm{m}}=\%$, soil moisture at middle spacing between two drained sub-soiler ruts;

$Q_{c}=\%$, soil moisture at center of drained sub-soiler rut;

$\rho_{\mathrm{d}}$ and $\rho_{\mathrm{w}}=$ soil and water density, gm/cm3;

$\mathrm{S}_{\mathrm{d}}$ and $\mathrm{D}_{\mathrm{d}}=$ draine sub-soiling drain spacing and depths.

The major aim of the present study was to identify the proper subsoiling system to improve clayey soil drainage. Also, to identify the effect of sub-soiling systems on soil moisture content, bulk density, soil penetration resistance and water flux.

\section{MATERIALS AND METHODS}

\section{Soil Site}

Experiments were carried out on a heavy clayey soil at Elhawawsha village, Daqahlia Governrate. Soil samples and experiment measurements values were taken before and after investigating the experiment to compare between them. The experimental area was divided into three main plots involved three sub-soiler depths 25, 50 and $75 \mathrm{~cm}$. Each main plot includes three sub-plots, which involved three lateral spaces between sub-soiling ruts $(200,400$ and $800 \mathrm{~cm})$. The used sub-soiler plough was shown in Fig. (1). Hence, the experimental area divided into nine plots. Each plot was represented as a fixed treatment to test the tillage depth and the lateral space. All experimental area was tilled by a chisel plough at $20 \mathrm{~cm}$ depth before sub-soiling tillage system. The winged chisel plough was 7 shares arranged on two rows and SAM tractor Perkins $150 \mathrm{HP}$ and $2800 \mathrm{~kg}$ by weight was used to perform all tillage treatments. The experimental design and the treatment illustration are shown in Fig. (2). The grown crop was onion crop which has fibrous roots. The tested soil samples and measurements were taken after three irrigations, the first, the second and the third irrigations were at 16/12/2011, 26/12/2011 and 6/1/2012 respectively. 
Elbanna, E. B. et al.

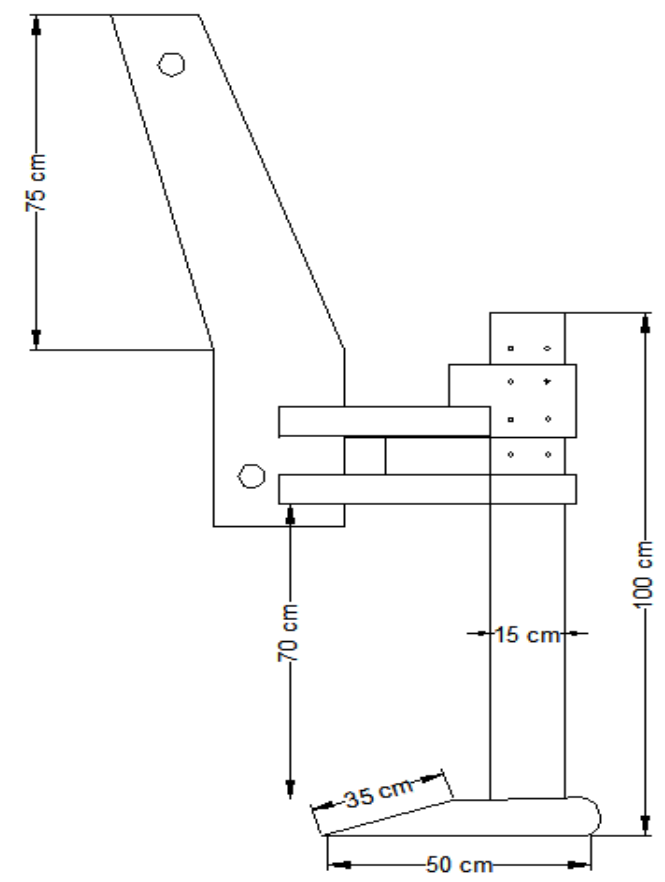

Fig. 1: Side view of the used mounted sub-soiling plough.

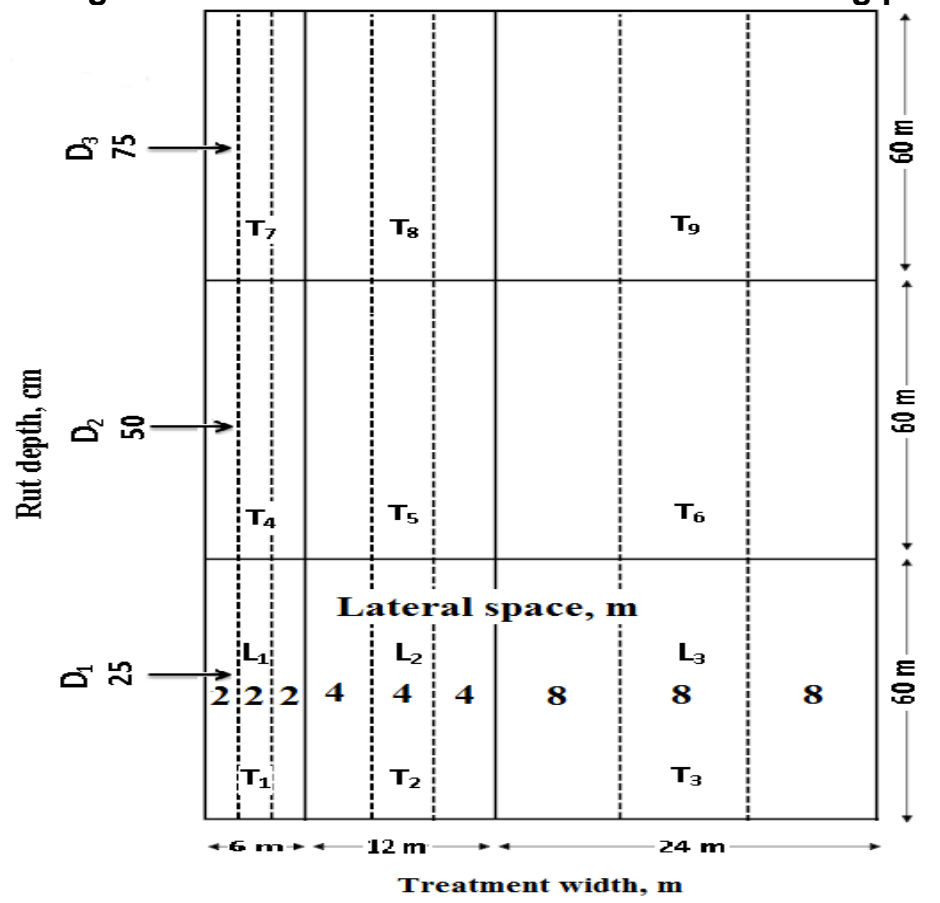

Fig. 2: Illustrate the experimental design and the tillage treatments. 


\section{Soil Mechanical Analysis}

Three soil samples were taken randomly from the whole area of the tested soil by soil core at the beginning of the experiment, collected together and carried to Micro Analysis Unit, Agricultural Chemistry Department, Faculty of Agricultural, Mansoura University to deduce the soil mechanical analysis. The results obtained from this analysis are represented in Table (A). The clay ratio and soil frictional angle were calculated according to (Elbanna and Witney 1987) as in the from:

$$
\begin{aligned}
& \mathrm{C}_{\mathrm{r}}=\frac{\% \text { clay }}{\% \text { sand }+\% \text { silt } \ldots \ldots \ldots . . .(6)} \\
& \tan \varphi=\frac{1}{1+2 \mathrm{Cr}} \ldots \ldots \ldots \ldots . . .(7)
\end{aligned}
$$

Table (A): Soil mechanical analysis, clay ratio and soil textural before tillage.

\begin{tabular}{|c|c|c|c|c|c|c|c|c|c|c|}
\hline \multicolumn{3}{|c|}{ Sand, \% } & Silt, \% & $\begin{array}{c}\text { Clay, } \\
\%\end{array}$ & $\mathbf{C r}$ & $\begin{array}{c}\boldsymbol{\varphi}, \\
\mathbf{d e g}\end{array}$ & $\begin{array}{c}\boldsymbol{\rho}_{\mathrm{b}, 3} \\
\mathbf{g} / \mathbf{c m}\end{array}$ & $\begin{array}{c}\text { Soil } \\
\text { textural }\end{array}$ & $\begin{array}{c}\text { Field } \\
\text { capacity, } \\
\%\end{array}$ & $\begin{array}{c}\text { wilting } \\
\text { point, } \\
\%\end{array}$ \\
\hline 1.586 & 17.615 & 19.201 & 27.187 & 53.612 & 1.156 & 16.80 & 1.22 & clayey & 37 & 16 \\
\hline
\end{tabular}

\section{Field Measurements:}

\section{Soil penetration resistance:}

Soil penetration resistance was measured by using cone penetrometer, model S4612, C.O.E. type. It was measured before sub-soiling at three soil depth 20,40 and $60 \mathrm{~cm}$, and after three sequence irrigations at the three soil depth 20,40 and $60 \mathrm{~cm}$, at the middle distance between subsoiling ruts in each sub-soiling treatment from the third day of irrigation to the tenth day.

\section{Determination of soil moisture content and soil bulk density:}

Soil sample were collected randomly before investigating the experiment at three soil layers of $0-20,20-40$ and $40-60 \mathrm{~cm}$. After tillage soil samples were collected from each sub-soiling treatment at sub-soiling ruts at its three sub-soiler tillage depth 25,50 and $75 \mathrm{~cm}$. It also collected after three sequence irrigation from each sub-soiling treatment from the third day to the tenth day at three soil depths $0-20,20-40$ and $40-60 \mathrm{~cm}$, at two positions: sub-soiling ruts and the middle distance between sub-soiling ruts. Soil samples were collected by using soil core. Soil samples were put in jars and weighed. Soil moisture content was determined by drying the jars with soil at $105^{\circ}$ for 24 hours in an oven. All jars were weighed after that and the following equation was used:

$$
\theta=\frac{W_{W}-W_{d}}{W_{W}} \times 100 \ldots \ldots \ldots \ldots(8)
$$


where:

$\theta=$ soil moisture content, $(\%) ; \quad \mathrm{W}_{\mathrm{w}}=$ soil wet weight, $(\mathrm{g})$;

$\mathrm{W}_{\mathrm{d}}=$ soil dry weight, $(\mathrm{g})$.

Hence, soil moisture content should be converted into an equivalent depth of water by multiplying its decimal value by the depth of the soil profile and the ratio of the soil bulk density to the density of water $\left(1 \mathrm{~g} / \mathrm{cm}^{3}\right)$, according to Witney (1988) and EL-Banna (1993).

where

$$
\text { Soil water, } \mathrm{mm}=\theta \text { (h) } \frac{\rho_{\mathrm{d}}}{\rho_{\mathrm{W}}} \ldots \ldots \ldots \ldots . . .(9)
$$

$$
\begin{array}{ll}
\Theta=\text { soil moisture content, } \operatorname{dim} ; & \rho_{\mathrm{d}}=\text { soil bulk density, } \mathrm{kg} / \mathrm{m}^{3} ; \\
\rho_{\mathrm{w}}=\text { water density, } \mathrm{Kg} / \mathrm{m}^{3} ; & \mathrm{h}=\text { depth of soil profile, } \mathrm{mm} .
\end{array}
$$

Soil bulk density estimated from the following equation:

$$
\rho_{\mathrm{b}}=\frac{\mathrm{Wd}}{\mathrm{V}}
$$

where:

$$
\rho_{b}=\text { Soil bulk density, }\left(\mathrm{g} / \mathrm{cm}^{3}\right) ; \quad \mathrm{W}_{\mathrm{d}}=\text { soil dry weight, }(\mathrm{g}) \text {; }
$$

$\mathrm{V}=$ soil total volume, $\left(\mathrm{cm}^{3}\right)$.

\section{Soil water flux measurement:}

A 0.33 bar and 15 bar soil moisture equipment's for extraction and measurements of soil moisture (at the executive device for land improvement, Dakahlia) were used to determine soil water flux of three soil profile depths 0 - 20, 20 - 40 and $40-60 \mathrm{~cm}$ after three sequence irrigations. Soil samples were taken from the third day to the tenth day after the three sequence irrigations at the three studied depth. Soil samples were sub-sampled with small core and saturated with and placed to the extraction apparatus of 0.33 and 15 bar to determine soil moisture at various tension pressures. Samples were weighed every time after three days a desired equilibrium was reached. Moisture content was calculated for all samples and converted into soil water head using the previous equation (9). Soil water head is expressing the soil water flux, $\mathrm{mm} /$ day.

Statistical Analysis:

Analysis of data for the soil penetration resistance, soil moisture content, bulk density and soil water flux were executed with the aid of the computerized statistical procedures of elementary statistics programs STATS, (version 2). 


\section{RESULTS AND DISCUSSION}

\section{Influence of Different Treatment on Soil Moisture Content and Bulk Density:}

Soil moisture content and bulk density values which obtained during the study showed that, the soil moisture content before tillage was higher than the values obtained after tillage through the three studied soil profile layers from all sub-soiling tillage treatments. It also found that, the soil moisture content increases with the gradually increment of the soil profile depth.

When compared the different treatments to each other after the first irrigation, the obtained values indicated that, the highest values of soil moisture content through the three studied soil profile depths at the third day (at field capacity) to the tenth day from irrigation were obtained from the third treatment that was tilled at $25 \mathrm{~cm}$ with a lateral space of $800 \mathrm{~cm}$, it was $(45.5$, 46.4 , and $47.24 \% \mathrm{w} / \mathrm{w})$ at the third day and $(35.02,37.23$, and $37.9 \% \mathrm{w} / \mathrm{w})$ at the tenth day for the three depths $0-20,20-40$, and $40-60 \mathrm{~cm}$, respectively. Also, the lowest values were obtained from the seventh treatment that was tilled at $75 \mathrm{~cm}$ with a lateral apace of $200 \mathrm{~cm}$, it was (38.72, 40.22, and $41.34 \% \mathrm{w} / \mathrm{w})$ at the third day and $(25.79,27.78$, and $28.43 \% \mathrm{w} / \mathrm{w}$ ) at the tenth day for the three studied depths respectively. It can also noticed that, the values of the fourth treatment that was tilled at $50 \mathrm{~cm}$ with a lateral space of $200 \mathrm{~cm}$ were slightly higher than the seventh treatment through the three soil depths. It was $(39.35,40.55$, and $41.75 \% \mathrm{w} / \mathrm{w})$ at the third day and $(27.09,28.92$, and $30.38 \% \mathrm{w} / \mathrm{w})$ at the tenth day. The plotted curves in Fig. (3) showed that, the seventh treatment had the lowest position beneath all the other plotted curves of the different treatment at the third and the tenth day from irrigation and the third treatment had the highest position over the other treatments.

The obtaining values explained that, the deep tillage of 75 and $50 \mathrm{~cm}$ with the narrower lateral spaces of $200 \mathrm{~cm}$ between sub-soiling ruts in both the seventh and the fourth treatment reduced the soil moisture content in comparison with the other treatments that were tilled at different deep tillage depths with a wider lateral spaces of 400 and $800 \mathrm{~cm}$. 
Elbanna, E. B. et al.

(a)

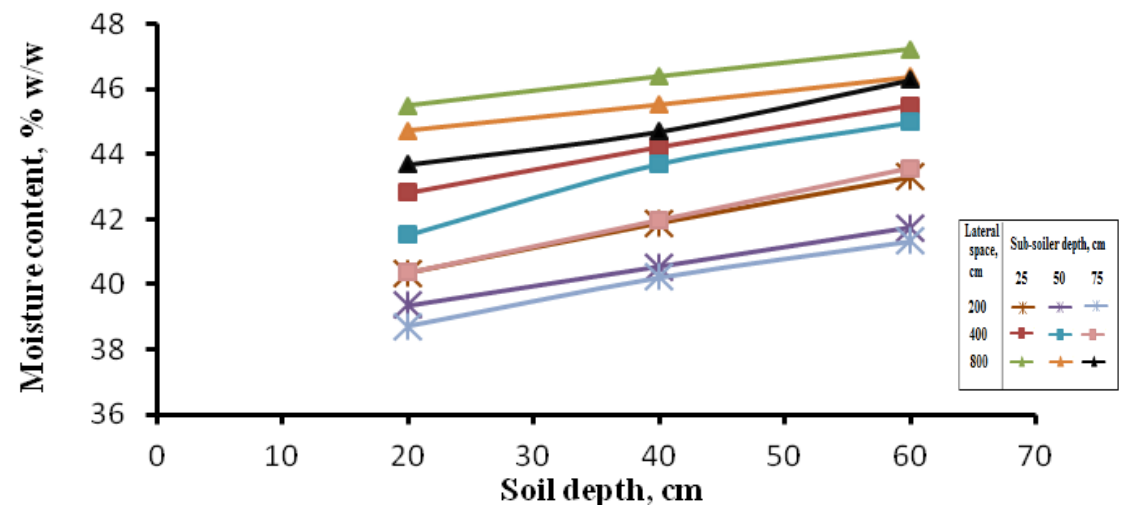

(b)

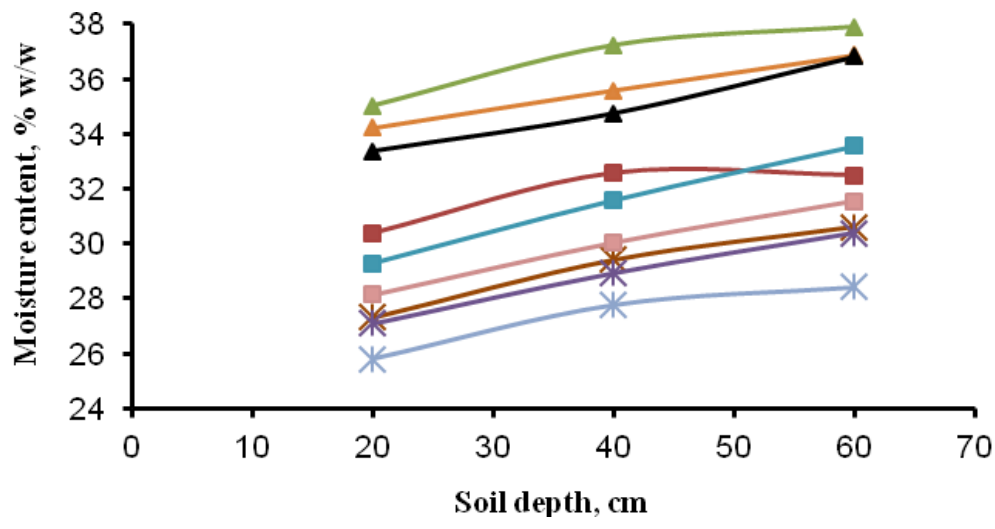

Fig. (3): Soil moisture content, $\% w / w$ of (a) the third day and (b) the tenth day after the first irrigation through the three studied depths for the different treatment.

Concerning, the soil water content data recorded from the sub-soiling ruts and the middle distance between sub-soiling ruts, it can found that, values of soil water content obtained at the sub-soiling ruts were lower than values obtained at the middle distance between sub-soiling ruts. Those lower values were due to the action of the excess loosening resulted from tilling with the sub-soiling plough at those positions. This loose made the soil particles have many and large pores, which can conserve water. Also, data explained that, the third treatment found to be holding more soil moisture content than the other treatment followed by the sixth treatment. This refers to that, with increasing the lateral space between sub-soiling ruts and decreasing tillage depth, more holding moisture content found. Soil moisture content values of the seventh treatment at the sub-soiling ruts and at the middle distance between ruts were extremely lower than values of other treatment and it dried rapidly from the third day to the tenth day of irrigation more than the other treatments, thus due to its narrower distance from ruts $(200 \mathrm{~cm})$ and its deep tillage ruts $(75 \mathrm{~cm})$ that make the position from the middle to the ruts keep a little soil moisture content. Those lower values 
because of the more loosening created in the narrower distance. The seventh treatment produces more enhancements of the soil physical properties than the other treatment. Similarly, the second and the third irrigations displayed the same trends which drawn from soil moisture content measurements of the first irrigation.

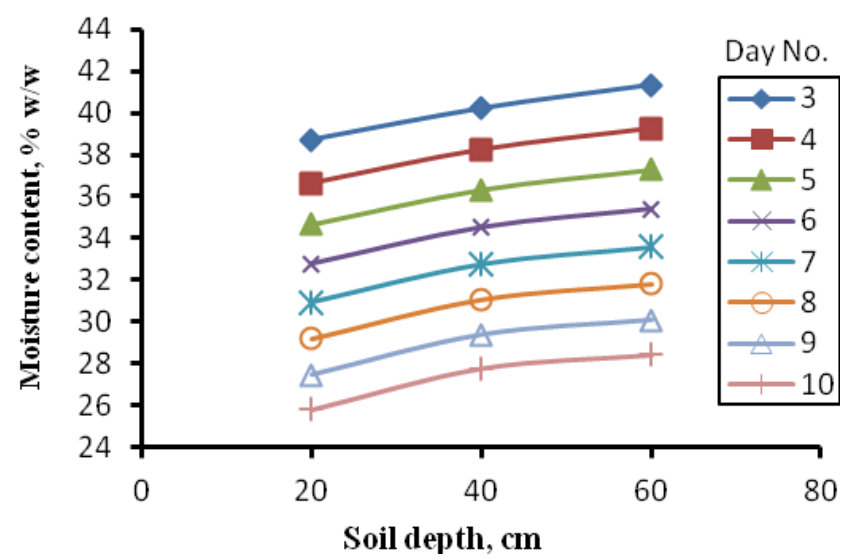

Fig. (4): Soil moisture content, $\% w / w$ from the third day to the tenth day after the first irrigation at the three studied depths for the seventh treatment.

An overview, from the soil bulk density measurements, it can deduced that, averaged values of bulk density which obtained after the three irrigations for all the sub-soiling treatments decreased comparing with the values obtained before sub-soiling. And the lowest values were found at the top surface layer, this was due to tilling with chisel plough at $20 \mathrm{~cm}$ depth where, a more pulverization occurred in the top layer. It decreased from 1.22 $\mathrm{g} / \mathrm{cm}^{3}$ to $1.14 \mathrm{~g} / \mathrm{cm}^{3}$ at the third day (field capacity) and it decreased to 1.17 $\mathrm{g} / \mathrm{cm}^{3}$ at the tenth day from the first irrigation.

\section{Soil Penetration Resistance:}

Soil penetration resistance is an indicator of soil compaction. It also can be an indicator that can used to evaluate tillage effects on soil physical properties. The obtained data showed that the mean value of the whole area before tillage was a large value $\left(951.52 \mathrm{kN} / \mathrm{m}^{2}\right)$ of soil penetration resistance at the depth of $20 \mathrm{~cm}$, after that it become larger $\left(1371.35 \mathrm{kN} / \mathrm{m}^{2}\right)$ at the depth of $40 \mathrm{~cm}$, and then it decrease to low value $\left(729.34 \mathrm{kN} / \mathrm{m}^{2}\right)$ at the depth of $60 \mathrm{~cm}$.

After the first irrigation, soil penetration resistance were decreased to a low values compared with the values before tillage systems. The plotted curves in Fig. (5) showed that, the third treatment which was tilled at $25 \mathrm{~cm}$, with a lateral space of $800 \mathrm{~cm}$ exhibited the lower values of soil penetration resistance until the tenth day has been reached for the three soil profile depth than of the other treatments $\left(599.87,723.98\right.$, and $\left.393.02, \mathrm{kN} / \mathrm{m}^{2}\right)$ at the third day and $\left(786.03,875.66\right.$ and $\left.544.71, \mathrm{kN} / \mathrm{m}^{2}\right)$ at the tenth day through the three studied profile depth $0-20,20-40$, and $40-60 \mathrm{~cm}$, respectively, this 
may be due to the highest water content that obtained in this treatment. That confirms the fact of which the soil penetration resistance is contrary with the soil moisture content. When the soil becomes more wet, the penetration resistance of the soil decreases and vice versa. And the seventh treatment which was tilled at $75 \mathrm{~cm}$, with a lateral space of $200 \mathrm{~cm}$, exhibited the higher values until the tenth day has been reached for the three soil profile depth than of the other treatments $\left(786.03,944.62\right.$, and $\left.565.39 \mathrm{kN} / \mathrm{m}^{2}\right)$ at the third day and $\left(951.5,1048.04\right.$, and $\left.698.1 \mathrm{kN} / \mathrm{m}^{2}\right)$ at the tenth day. This was due to the deep tillage of $75 \mathrm{~cm}$ with the narrower lateral space of $200 \mathrm{~cm}$ between sub-soiling ruts which conducted at the seventh treatment. So, higher loosening action occurred and made the soil dried rapidly from the third day to the tenth day and the soil recorded higher soil penetration resistance than the other treatment.

The result of tilled all the area with chisel plough was shown in the top layer. The values of soil penetration resistance at the top layer until $20 \mathrm{~cm}$ depth were lower than the values at the subsequent layer until $40 \mathrm{~cm}$ depth. These obtaining values were because of the more pulverization occurred in the top layer by chisel plough. Consideration to the soil penetration resistance data of the second and the third irrigations, it can found the same trends which drawn from the first irrigation.

After normalized experimental data exclusive the soil penetration resistance, soil moisture content, clay ratio and soil bulk density for three irrigation times. The data were statistical analysis at various treatments in the tillage depth and at the lateral spacing between sub-soiling ruts. Each treatment analyzed individual from the first to the third irrigation and combined all the three irrigations to obtain the cone index equation coefficients (the cohesive and the friction coefficients), their standard errors and their explanation from the equation (1) which developed by Elbanna (2001) and Elbanna and Witney (1987).

Because of the present study was conducted on three studied soil profile depth $(0-20,20-40$, and $40-60 \mathrm{~cm})$, the previous equation (11) was developed as statistical tested to obtain the equation coefficients. The equation is developed by adding the soil profile depth $(\mathrm{m})$ to the two parts of the equation and it becomes:

$$
\left.\mathrm{CI}=\left[\mathrm{k}_{\mathrm{C}} \cdot \mathrm{d} \cdot \mathrm{Cr} \cdot \mathrm{e}^{-\mathbf{0 . 0 1 0 / ( 1 + C r )}}+\mathrm{k}_{\Phi} \frac{\gamma}{\mathrm{d}(1+2 \mathrm{Cr})}\right]\right]^{\pi /(1+2 \mathrm{Cr})}
$$

where:

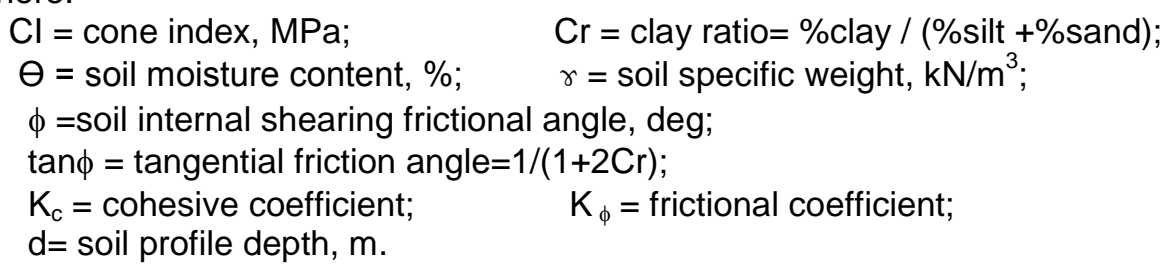



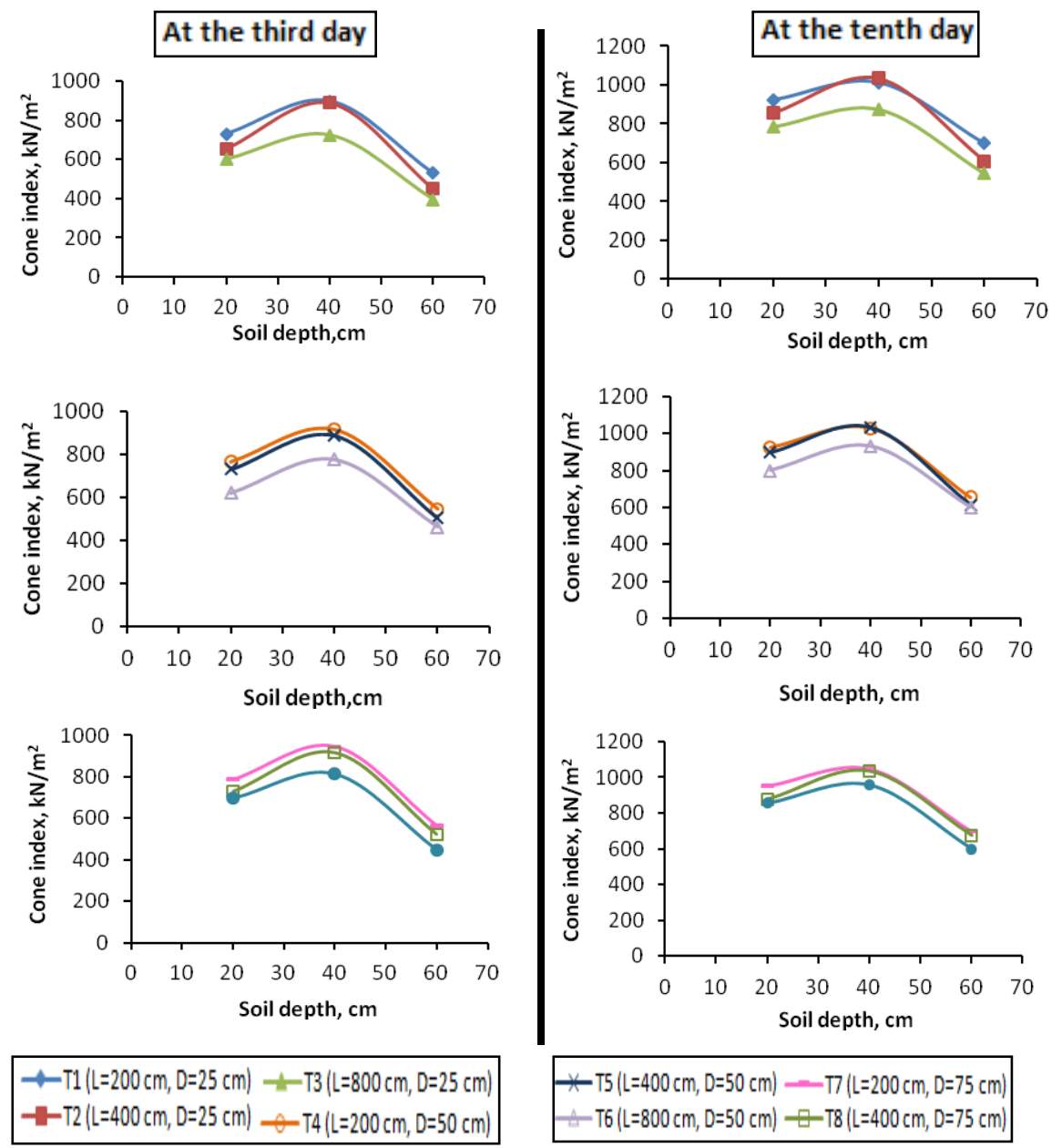

$-T 9(\mathrm{~L}=800 \mathrm{~cm}, \mathrm{D}=75 \mathrm{~cm})$

Fig. (5): Soil penetration resistance for all different treatments at the third and the tenth day after the first irrigation through the three studied soil profile depth.

Where, the cohesive component is multiplied by the soil profile depth because of soil cohesive increases with the increasing of the soil depth to a defined depth and the friction component is divided by the soil depth where, the friction component is affected by the soil specific weight as, the soil friction increases with the increasing of soil specific weight and the soil depth is proportional inversely with the soil specific weight. As, the top layer of the soil was more looses than the following layers due to tilling it with the chisel plow, it can contain a large porous which drain the water more rapidly than the other layers and it drained consequently to the following layers, either the 
Elbanna, E. B. et al.

top layer is susceptible to evaporation. So, the top layer has a greater value of soil specific weight than the other layers and thus, the soil specific weight is decreases with the increasing of soil depth and the decreasing of soil friction.

From the results in Table (1), it can be concluded that the fourth and the seventh treatment which was tilled at 50 and $75 \mathrm{~cm}$, with a lateral space of $200 \mathrm{~cm}$ explained the high correlation coefficient consideration to the three irrigations than the other treatment. There were 95.16 and $94.97 \%$ at the first irrigation, 95.54 and $95.47 \%$ at the second irrigation and 95.45 and $95.28 \%$ at the third irrigation for the fourth and the seventh treatment respectively.

Table (1): Values of cone index resistance coefficients, their standard error and percentage of explanation for all treatment after three sequence irrigations:

\begin{tabular}{|c|c|c|c|c|c|c|c|}
\hline \multicolumn{2}{|c|}{ Treatments } & \multicolumn{2}{|c|}{ Coefficients } & \multicolumn{2}{|c|}{ standard errors } & \multirow[b]{2}{*}{ Expl., \% } & \multirow[b]{2}{*}{ DF. } \\
\hline $\begin{array}{c}\text { lateral } \\
\text { space, } \mathbf{c m}\end{array}$ & $\begin{array}{c}\text { Tillage } \\
\text { depth, } \mathrm{cm}\end{array}$ & $\mathrm{K}_{\mathrm{c}}$ & $\mathrm{K}_{\varphi} * 10^{-3}$ & $\mathrm{~K}_{\mathrm{c}}$ & $\mathrm{K}_{\varphi} * 10^{-4}$ & & \\
\hline \multicolumn{8}{|c|}{ (a) after the first irrigation } \\
\hline \multirow{3}{*}{200} & 25 & 0.34897 & 1.49778 & 0.047262 & 1.57996 & 95.4 & 23 \\
\hline & 50 & 0.32691 & 1.57229 & 0.048559 & 1.63023 & 95.16 & 23 \\
\hline & 75 & 0.3395 & 1.59127 & 0.050575 & 1.70311 & 94.97 & 23 \\
\hline \multirow{3}{*}{400} & 25 & 0.31893 & 1.45381 & 0.058751 & 1.95163 & 92.48 & 23 \\
\hline & 50 & 0.32222 & 1.53619 & 0.053779 & 1.78355 & 94.03 & 23 \\
\hline & 75 & 0.34728 & 1.49093 & 0.052049 & 1.74303 & 94.43 & 23 \\
\hline \multirow{3}{*}{800} & 25 & 0.26703 & 1.32306 & 0.045521 & 1.49094 & 94.08 & 23 \\
\hline & 50 & 0.31298 & 1.30968 & 0.046679 & 1.53578 & 94.42 & 23 \\
\hline & 75 & 0.29243 & 1.50976 & 0.048452 & 1.61439 & 94.65 & 23 \\
\hline \multicolumn{2}{|c|}{ Combined } & 0.32056 & 1.47493 & 0.016677 & 0.55506 & 94.06 & 215 \\
\hline \multicolumn{8}{|c|}{ (b) after the second irrigation } \\
\hline \multirow{3}{*}{200} & 25 & 0.33304 & 1.30556 & 0.047999 & 1.59489 & 94.36 & 23 \\
\hline & 50 & 0.32357 & 1.41994 & 0.043823 & 1.45688 & 95.54 & 23 \\
\hline & 75 & 0.32149 & 1.44492 & \begin{tabular}{|l|}
0.044246 \\
\end{tabular} & 1.48856 & 95.47 & 23 \\
\hline \multirow{3}{*}{400} & 25 & 0.29978 & 1.35347 & 0.053243 & 1.75608 & 92.93 & 23 \\
\hline & 50 & 0.31712 & 1.37618 & \begin{tabular}{|l|}
0.051501 \\
\end{tabular} & 1.71496 & 93.61 & 23 \\
\hline & 75 & 0.31807 & 1.37490 & 0.052122 & 1.72296 & 93.59 & 23 \\
\hline \multirow{3}{*}{800} & 25 & 0.35104 & 0.95054 & \begin{tabular}{|l|}
0.038747 \\
\end{tabular} & 1.26689 & 95.25 & 23 \\
\hline & 50 & 0.35086 & 0.99657 & 0.039539 & 1.29819 & 95.21 & 23 \\
\hline & 75 & 0.34776 & 1.16881 & \begin{tabular}{|l|}
0.044126 \\
\end{tabular} & 1.47844 & 94.78 & 23 \\
\hline \multicolumn{2}{|c|}{ Combined } & 0.32940 & 1.26643 & \begin{tabular}{|l|}
0.015481 \\
\end{tabular} & 0.51343 & 94.06 & 215 \\
\hline
\end{tabular}


Table (1) Cont'd.

\begin{tabular}{|c|c|c|c|c|c|c|c|}
\hline \multicolumn{2}{|c|}{ Treatments } & \multicolumn{2}{|c|}{ Coefficients } & \multicolumn{2}{|c|}{ standard errors } & \multirow[b]{2}{*}{ Expl., \% } & \multirow[b]{2}{*}{ DF. } \\
\hline $\begin{array}{c}\text { lateral } \\
\text { space, } \mathbf{c m}\end{array}$ & $\begin{array}{c}\text { Tillage } \\
\text { depth, cm }\end{array}$ & $\mathrm{K}_{\mathrm{c}}$ & $K_{\varphi}^{*} 10^{-3}$ & $\mathrm{~K}_{\mathrm{c}}$ & $K_{\varphi}^{*} 10^{-4}$ & & \\
\hline \multicolumn{8}{|c|}{ (c) after the third irrigation } \\
\hline \multirow{3}{*}{200} & 25 & 0.32203 & 1.33361 & 0.047807 & 1.57878 & 94.41 & 23 \\
\hline & 50 & 0.28403 & 1.45939 & 0.042987 & 1.41053 & 95.45 & 23 \\
\hline & 75 & 0.28811 & 1.49802 & 0.044656 & 1.5 & 95.28 & 23 \\
\hline \multirow{3}{*}{400} & 25 & 0.28738 & 1.32647 & 0.053826 & 1.76278 & 92.45 & 23 \\
\hline & 50 & 0.31169 & 1.31818 & 0.052551 & 1.73917 & 93.08 & 23 \\
\hline & 75 & 0.32051 & 1.35655 & 0.051235 & 1.69241 & 93.78 & 23 \\
\hline \multirow{3}{*}{800} & 25 & 0.34076 & 0.92341 & 0.039169 & 1.26883 & 94.93 & 23 \\
\hline & 50 & 0.34623 & 0.94199 & 0.037107 & 1.21032 & 95.54 & 23 \\
\hline & 75 & 0.33211 & 1.13518 & 0.043384 & 1.42734 & 94.71 & 23 \\
\hline \multicolumn{2}{|c|}{ Combined } & 0.31505 & 1.25413 & 0.015543 & 0.51181 & 93.81 & 215 \\
\hline \multicolumn{2}{|c|}{$\begin{array}{l}\text { Combined for all } \\
\text { irrigations }\end{array}$} & 0.32629 & 1.28796 & 0.019566 & 0.75853 & 83.31 & 645 \\
\hline
\end{tabular}

\section{Estimation of Soil Water Flux for The Different Treatments:}

Soil water flux indicates a constant daily rate of water movement draining through the soil profile. Soil water flux, (mm/day) was estimated for all treatment at the three sequence irrigation. All data were normalized and statistical analysis to obtain the drainage coefficients, their standard errors and their explanation from the empirical drainage equation (5) which developed by Elbanna (2010) and then a prediction of drainage factor, $(\mathrm{mm} /$ day) were evaluated. Table (2) presented the drainage coefficients, their standard errors and their explanation for the combined data of the three sequence irrigations.

Table (2): Values of the drainage coefficients, their standard errors and their percentage of explanation for the combined data of the three sequence irrigations:

\begin{tabular}{|c|c|c|c|c|c|c|c|}
\hline \multicolumn{2}{|c|}{ Drainage coefficients ${ }^{*} \mathbf{1 0}^{-2}$} & \multicolumn{3}{c|}{ Standard errors $^{*} \mathbf{1 0}^{-3}$} & \multirow{2}{*}{ Expl., \% } & \multirow{2}{*}{ DF. } \\
\hline $\mathbf{K}_{\mathbf{i}}$ & $\mathbf{K}_{\boldsymbol{\theta}}$ & $\mathbf{K}_{\text {sd }}$ & $\mathbf{K}_{\mathbf{i}}$ & $\mathbf{K}_{\boldsymbol{\theta}}$ & $\mathbf{K}_{\text {sd }}$ & & \\
\hline 120.182 & 6.2312 & -0.12107 & 18.4294 & 2.7422 & 0.1874 & 98.62 & 647 \\
\hline
\end{tabular}

Considering to the values of the measured soil water flux which displayed in Fig. (6) for all the different treatments after the first irrigation and consideration to values obtained after the second and the third irrigations, it can deduced that, the treatments which were deep tilled with a narrower lateral spacing achieved the highest rate of soil water flux from the third day to the tenth day of the three irrigations. This was more evident in the seventh and the fourth treatments which were tilled at 75 and $50 \mathrm{~cm}$, respectively with a lateral spacing of $200 \mathrm{~cm}$ followed by the eighth and the fifth treatments which were tilled at 75 and $50 \mathrm{~cm}$, respectively with a lateral spacing of 400 $\mathrm{cm}$. This was due to the deep tilled with a narrower lateral spacing that made more losses between soil particles, so a more infiltration make from the top soil layer to the following layers and a more water drained during days after 
irrigation from the third day to the tenth day. This clarified that, the lower soil tension exist in the soil which deep tilled with a narrower lateral spacing. Per contra, the treatment which tilled at low depth with a lateral spacing did not achieve any enhancement in the daily rate of soil water flux in comparison with the other treatment. This was more evident in the third treatment which was tilled at $25 \mathrm{~cm}$ with a lateral spacing of $800 \mathrm{~cm}$.
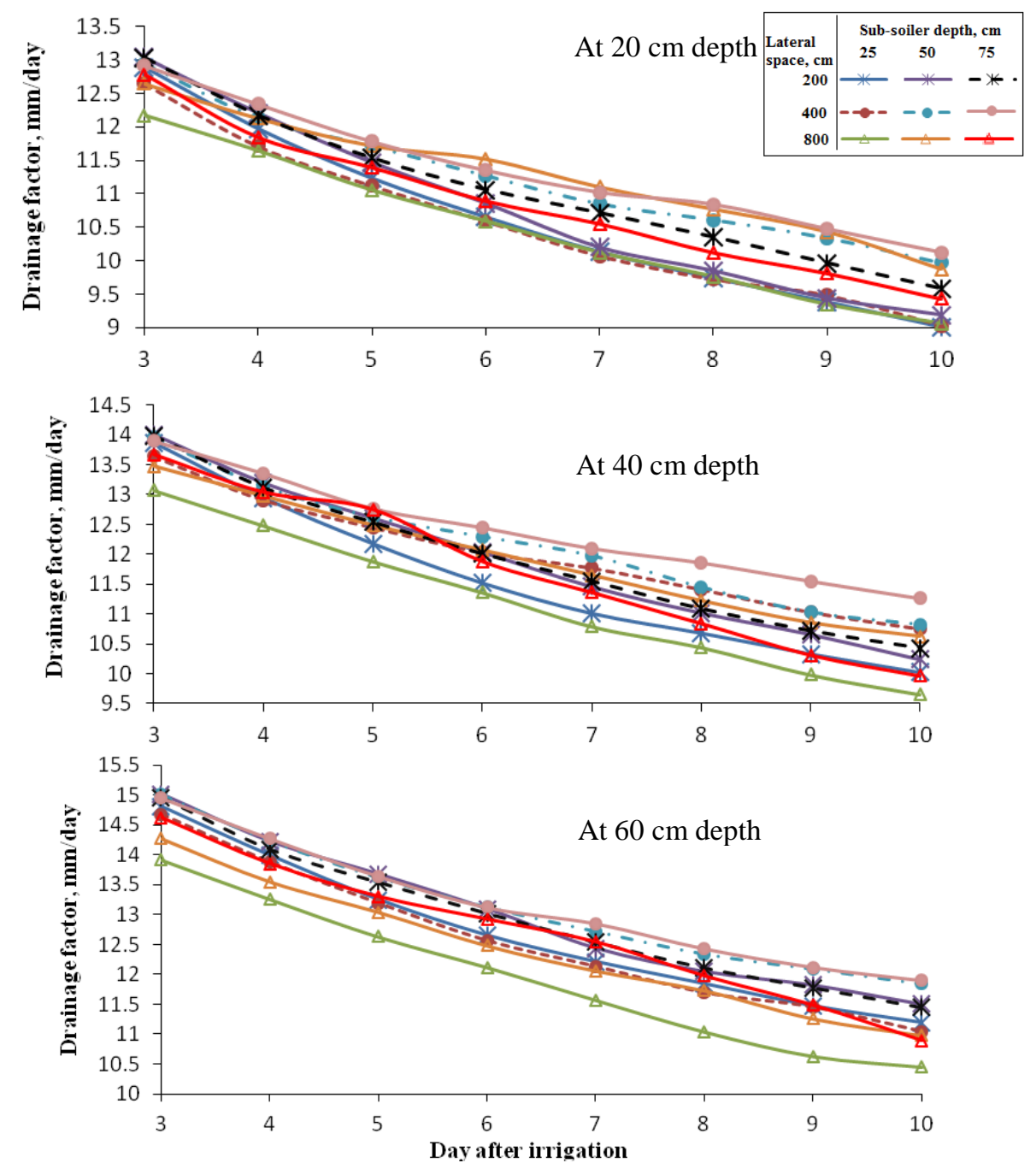

Fig. (6): Drainage factor, $\mathrm{mm} / \mathrm{day}$ from the third day to the tenth day after the first irrigation for the different treatments at three soil profile depth.

\section{CONCLUSIONS}

It can concluded that, the treatment which was deep tilled at $75 \mathrm{~cm}$, with a lateral spacing of $200 \mathrm{~cm}$, achieved the lowest values of soil moisture 
content and exhibited more homogeneously moisture distribution through the soil profile followed by the treatment which was deep tilled at $50 \mathrm{~cm}$, with a lateral spacing of $200 \mathrm{~cm}$. Also, it exhibited the higher value of soil penetration resistance than the other treatments but, it was lower than its value before sub-soiling. Thus was due to the higher loosening action which occurred and made the soil dried rapidly from the third day to the tenth day which lead to decrease the moisture content and the soil recorded higher soil penetration resistance than the other treatment.

It can also found that, the treatments which were tilled at 75 and 50 $\mathrm{cm}$, respectively with a lateral spacing of $200 \mathrm{~cm}$ followed by the treatments which were tilled at 75 and $50 \mathrm{~cm}$, respectively with a lateral spacing of 400 $\mathrm{cm}$, achieved the highest rate of soil water flux from the third day to the tenth day of the three irrigation. So, it can concluded that, as the lateral space between sub-soiling ruts decreases with an increase in the tillage depth, the soil achieves the lowest values of moisture content and produces more enhancement of soil physical properties.

\section{REFERENCES}

Allen, R. G.; L. S. Pereira; D. Raes and M. Smith. (1998) Crop evapotranspiration guidelines for computing crop water requirements. Irrigation and Drainage paper 56, FAO, Rome, 300p.

Borghei, A.M.; J. Taghinejad; S. Minaei; M. Karimi and M. Ghasemi varnamkhasti. (2008) Effect of subsoiling on soil bulk density, penetration resistance, and cotton yield in northwest of iran. Int. J. Agri. Biol., 10: 120-123.

Elbanna, E.B. and B.D. Witney (1987) Cone peneteration resistance equation as a function of clay ratio, soil moisture content and specific weight. J. Terramech, 24(4): 41-56.

Elbanna, E.B. (1993) Moisture tension and hydraulic conductivity in agricultural soils. Misr J. Agr. Eng., 10(4): $722-737$.

Elbanna, E. B. (2001) Comparative studies of three soil strength methods on sandy soils (Part I). J. Agric. Sci., Mansoura Univ., 26(12): 7929-7942.

Elbanna, E.B. (2008) Daily soil water flux as a function of hydraulic conductivity and moisture content. The $3^{\text {rd }}$ International Scientific Conference for Environment, South Valley Univ., PP: 1-15.

Elbanna, E.B.; M.A. El-saadany and N. Mansour. (2010) Clay and heavy clay soils improvement water movement by application of sub-soiling methods. J. Soil Sci. and Agric. Engineering, Mansoura Univ., Vol.1 (7): 723- 738.

Hong-ling, Q.; G. Wang-sheng; M. Yue-cum; M. Li; C. Zhe and C. Chun-lan. (2008) Effects of subsoiling on soil moisture under no-tillage for two years. J. Agric. Sci. in China. 7(1): 88-95.

Nitant, H.C.; Pratap-Singh and P. Singh. (1995) Effects of deep tillage on dryland production of redgram (Cajanus cajan L.) in Central India. Soil and Tillage Research. 34 (1): 17-26.

Prinzio, L.A. DI; T.J.C.Magdalena and V.C.D. Ayaia. (1996) Comparative test of three non-conventional sub-soiling techniques. Agro-Ciencia 
Elbanna, E. B. et al.

Argentina., 12(1): 37-42.

Prinzio, L.A. DI; V.C.D. Ayaia and T.J.C. Magdalena. (1997) Energetic test of different sub-soiling techniques and its effects upon the soil bulk density. Agro-Ciencia Argentina., 13(1): 61-67.

Thomas, W.; G. Robert; R. Richard; Topielec and W. Howard. (1994) Soil water monitoring measurement. Washington State Univ. Cooperative Extension, PNW 0475, USA, 34P.

Witney, B.D. (1988) Choosing and using farm machines. Text book (1st publ. 1988). Chapter: (Soil, Weather and Workdays), pp : 205-255. Longman house, Burnt Mill, Harlow.

\section{تحسين صرف الأراضى الطينية فى محافظة الدقهلية

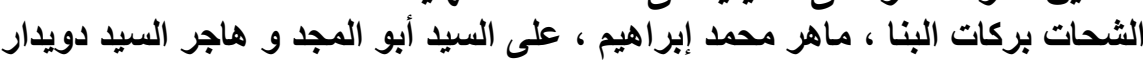

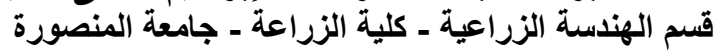

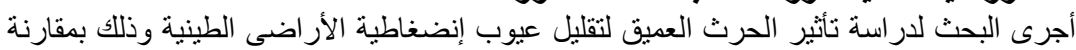

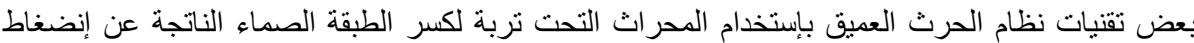

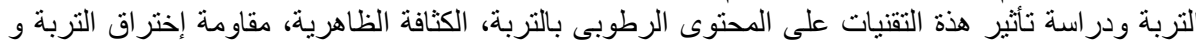

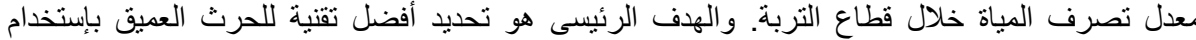

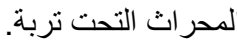

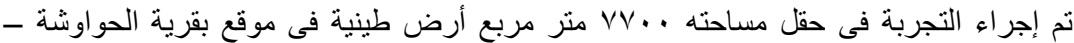

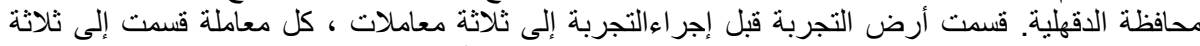

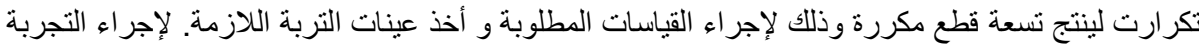

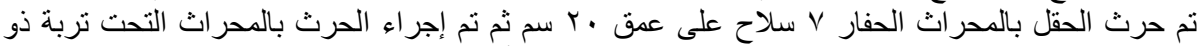

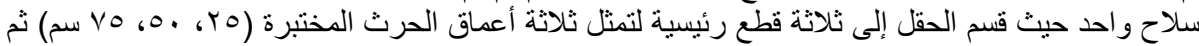

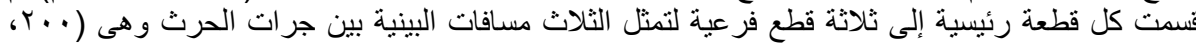

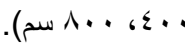

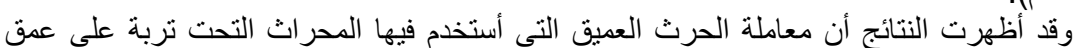

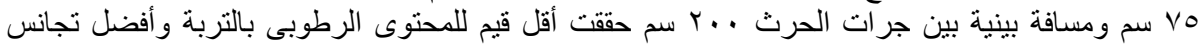

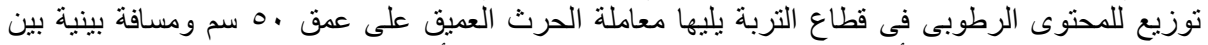

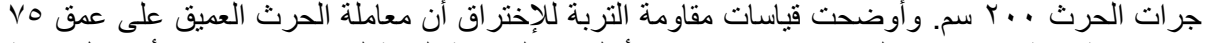

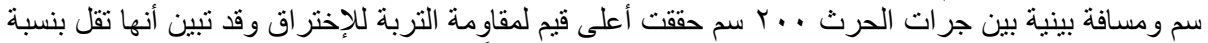

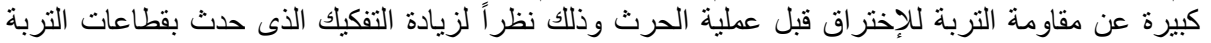

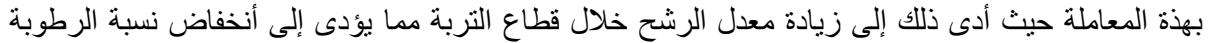

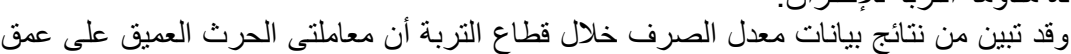
وبالتالى زيادة مقاومة التربة للإختراق.

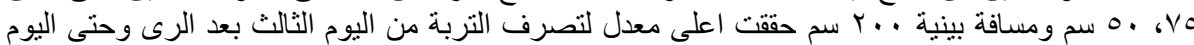

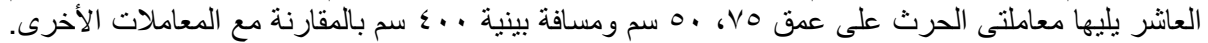

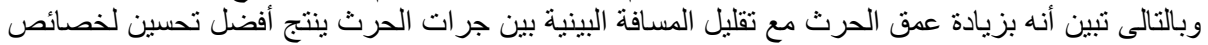

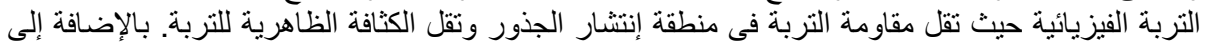
تحسين معدل تصرف التربة اليومى وتجانس توزيع المحتوى الرطوبى خلال قطاعات التربة.

كلية الزراعة - جامعة المنصورة كلية الزراعة - جامعة كفر الثيخ

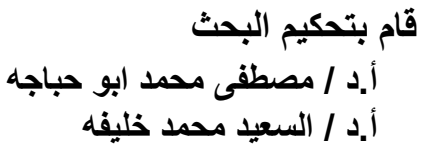


J. Soil Sci. and Agric. Eng., Mansoura Univ., Vol. 4 (9), September, 2013 